\title{
Adherence of Ureaplasma urealyticum to human epithelial cells
}

\author{
D. G. E. Smith, W. C. Russell and D. Thirkell
}

Author for correspondence: D. Thirkell. Tel: +44334 463410. Fax: +44334463400.

Division of Cell and

Molecular Biology, School of Biological and Medical Sciences, University of St Andrews, Irvine Building, North Street, St. Andrews, Fife KY16 9AL, UK

\begin{abstract}
Adherence of Ureaplasma urealyticum cells to eukaryotic cell monolayers was quantified using the Bertholet assay to monitor ammonia produced from urea by ureaplasma urease. Adherence was abolished by pre-treatment of ureaplasmas with HeLa cell extracts and inhibited to varying degrees by pretreatment of the ureaplasmas with $\mathbf{N}$-acetylneuraminic acid, specific antisera and monoclonal antibodies. The data suggest the presence of several ureaplasma adhesins, some of which are species- or serotype-specific and some of which are proteinaceous and antigenic. The serotype-8-specific $96 \mathrm{kDa}$ surface-expressed antigen may be one adhesin. Pre-treatment of HeLa cell monolayers with neuraminidase significantly reduced ureaplasma adherence and, using a novel 'immunoblot adherence assay', ureaplasmas were shown to bind to a number of HeLa cell components, three of which appear to terminate in sialic acid.
\end{abstract}

Keywords: Ureaplasma urealyticum, adherence

\section{INTRODUCTION}

The establishment of a host-micro-organism relationship often involves an adherence-mediated, intimate association of the micro-organism with host cell surfaces. A number of mycoplasmas adhere to epithelial cells of the urogenital or respiratory tract mucous membranes. Being wall-less and lacking fimbriae, mycoplasmal components responsible for attachment must be part of the cell membrane (Razin \& Jacobs, 1992). These components are usually referred to as adhesins. The mechanism(s) of adherence to host tissues for certain mycoplasmas, via their surface-expressed adhesin(s), continue to be documented (Razin \& Jacobs, 1992). However, little information is available in this regard for Ureaplasma urealyticum. So far, it has been demonstrated that $U$. urealyticum can adhere to urethral epithelia (Shepard \& Masover, 1979), spermatozoa (Busalo et al., 1984), fibroblasts (Masover et al., 1977), and guinea-pig and human red blood cells (Robertson \& Sherburne, 1991; Saada et al., 1991). Furthermore, two separate reports indicated that HeLa cells may be used to study ureaplasma attachment (Alfa et al., 1986; McGarrity \& Kotani, 1986).

We have thus aimed to investigate the adherence of $U$. urealyticum with a view to obtaining data on the nature of both the eukaryotic cell receptor(s) and the ureaplasma

Abbreviations: $C C U$, colour changing units; mAb; monoclonal antibody; NANA, $\mathrm{N}$-acetylneuraminic acid. adhesin(s). For this purpose, HeLa cell monolayers have been utilized as the eukaryotic model since this cell line is of genitourinary epithelium origin.

\section{METHODS}

Chemicals. Unless otherwise stated, all chemicals were obtained from Sigma.

Prokaryotic and eukaryotic cells. U. urealyticum serotype 8 (T960) was a gift from D. Taylor-Robinson (St Mary's Hospital Medical School, London). Two types of eukaryotic cells were used as monolayers: an SV40-transformed human uroepithelial cell line which was a gift from A. Riches (School of Biological and Medical Sciences, University of St Andrews, Scotland, UK), and HeLa cells.

Culture and harvesting of ureaplasmas. Ureaplasmas were cultured as described previously (Precious et al., 1987; Thirkell et al., 1989a) except that the medium contained either $20 \%(\mathrm{v} / \mathrm{v})$ horse serum (SeraLab) or $10 \%(\mathrm{v} / \mathrm{v}$ ) foetal calf serum (SeraLab) and the culture $\mathrm{pH}$ was not allowed to rise beyond $7 \cdot 5$. Where required, ureaplasmas were harvested (Precious et al., 1987; Thirkell et al., 1989a), washed and resuspended in Dulbecco's phosphate-buffered saline 'A' (PBS) (Dulbecco \& Vogt, 1954) or Tris-buffered saline (TBS; $50 \mathrm{mM}$ Tris $/ \mathrm{HCl}$, pH $7 \cdot 4$, $200 \mathrm{mM} \mathrm{NaCl}, 5 \mathrm{mM} \mathrm{KCl}$ ) and used in adhesion assays either directly or after pre-treatment of the ureaplasma cells.

Pre-treatment of $\boldsymbol{U}$. urealyticum. When required, ureaplasmas were subjected to one of the following procedures.

(i) Suspensions were incubated $\left(30 \mathrm{~min}, 20^{\circ} \mathrm{C}\right.$ ) with a $1 / 500$ dilution (in PBS) of various antibodies, viz. homologous 
polyclonal antiserum raised in rabbit; polyclonal antiserum against $U$. urealyticum serotype $4(11860)$ raised in mice; monoclonal antibodies (mAbs) recognizing the $96 \mathrm{kDa}$ serotype-8-specific surface-expressed antigen (Thirkell et al., 1990 ) or the $16 / 17 \mathrm{kDa}$ serocluster-specific ureaplasma surface antigens (Thirkell et al., 1989b); uncharacterized ureaplasma $\mathrm{mAbs}$, or $\mathrm{mAbs}$ or polyclonal antisera against non-ureaplasma antigens. Preliminary experiments (data not shown) indicated that antibodies diluted 1 in 500 produced maximal inhibition of adherence at the ureaplasma cell concentration used.

(ii) Glucose $(100 \mathrm{mM})$ or $N$-acetylneuraminic acid (NANA; $10 \mathrm{mM}$ ) in PBS were each added to ureaplasma suspensions immediately prior to incubation with epithelial cells.

(iii) Ureaplasma suspensions were incubated $\left(30 \mathrm{~min}, 20^{\circ} \mathrm{C}\right.$ ) with HeLa cell extracts (final concentration $500 \mu \mathrm{g}$ protein $\mathrm{ml}^{-1}$ ). Extracts were prepared by first scraping off the HeLa cell monolayers into PBS, transferring the suspensions into Eppendorf tubes, centrifugation $\left(11500 \mathrm{~g}, 5 \mathrm{~min}, 20^{\circ} \mathrm{C}\right)$, washing $(\times 2)$ of the pellets with PBS and then resuspension in solubilization buffer $[10 \mathrm{mM}$ Tris $/ \mathrm{HCl}, \mathrm{pH} 7 \cdot 4,5 \mathrm{mM}$ EDT A, $650 \mathrm{mM} \mathrm{NaCl}, 1 \mathrm{mM}$ phenylmethylsulphonyl fluoride (PMSF), $0.1 \%, \mathrm{w} / \mathrm{v}, \mathrm{NaN}_{3}$ ]. The suspensions were then sonicated (MSE Soniprep $150,3 \times 10 \mathrm{~s}$, on ice), pooled, centrifuged (as above) and the supernatant (extract; protein concentration between 5 and $6 \mathrm{mg} \mathrm{ml}^{-1}$ ) used, after appropriate dilution into the ureaplasma suspension (see above), or stored at $-20^{\circ} \mathrm{C}$ until required.

(iv) Ureaplasma suspensions were subjected to proteolysis by the following methods. (a) Incubation $\left(20 \mathrm{~min}, 37^{\circ} \mathrm{C}\right)$ in TBS containing $0.6 \mathrm{mM}$ EDTA in the presence of 100,200 or $500 \mu \mathrm{g}$ trypsin $\mathrm{ml}^{-1}$. Digestion was terminated by addition of the inhibitor $\mathrm{N} \alpha$-p-tosyl-L-lysine-chloromethyl ketone to a final concentration of $200 \mu \mathrm{g} \mathrm{m} l^{-1}$. (b) Incubation $\left(20 \mathrm{~min}, 37^{\circ} \mathrm{C}\right.$ ) in TBS with proteinase $\mathrm{K}$ at a final concentration of $100 \mu \mathrm{g} \mathrm{ml}{ }^{-1}$, or incubation $\left(20 \mathrm{~min}, 37^{\circ} \mathrm{C}\right)$ in $50 \mathrm{mM}$ sodium acetate, $200 \mathrm{mM}$ $\mathrm{NaCl}, 5 \mathrm{mM} \mathrm{KCl}, \mathrm{pH} 4 \cdot 7$, with papain at a final concentration of $100 \mu \mathrm{g} \mathrm{ml}^{-1}$. In each case, proteolytic activity was terminated by addition of the ureaplasma suspension to medium containing $20 \%(\mathrm{v} / \mathrm{v})$ horse serum.

In some instances (see Results), ureaplasmas were subjected to two or more of the above pre-treatments. It was shown that none of the pre-treatments, alone or in combination, with the exception of proteinase $\mathrm{K}$ or papain, produced any reduction in $U$. urealyticum viability as determined by monitoring colour changing units (ccu) $\mathrm{ml}^{-1}$ of the suspensions as described previously (Precious et al., 1987).

\section{Eukaryotic cell culture monolayers}

(a) Maintenance and preparation for adhesion assays. HeLa cells were cultured as monolayers in $75 \mathrm{~cm}^{2}$ disposable culture flasks (Corning) in G-MEM medium (Gibco) containing $10 \%(\mathrm{v} / \mathrm{v})$ newborn calf serum, from which they were subcultured every 3-4 d into fresh $75 \mathrm{~cm}^{2}$ flasks, $25 \mathrm{~cm}^{2}$ flasks or into 24 -well flatbottomed plates (Corning). This involved treatment of the monolayers with trypsin-EDTA $(0.05 \%$, w $/ \mathrm{v}$, trypsin, $0.02 \%$, $w / v$, EDTA in PBS) followed by resuspension in culture medium and introduction into fresh cultureware. Treatment of the HeLa cell monolayers under the conditions applied above (i.e. suspension in growth medium or buffer, with or without trypsin or antibodies) did not noticeably alter the viability of the cells $(\geqslant 98 \%)$ as monitored by microscopy using trypan blue exclusion.

Monolayers of the SV40-transformed human uroephithelial cell line were maintained and cultured in supplemented Hams F12 medium as described elsewhere (Armitage et al., 1991).
Before use, both cell lines were shown to be mycoplasma-free by DAPI staining (Russell et al., 1975).

(b) Use in adherence assays. All monolayers were cultured to $90-100 \%$ confluence and, where required, HeLa cell monolayers were incubated (pre-treated) with neuraminidase (final concentration of $0 \cdot 15 \mathrm{U} \mathrm{ml}^{-1} ; 30 \mathrm{~min}$ at $37^{\circ} \mathrm{C}$ ) prior to use in assays.

(c) Assay of adherence of $U$. urealyticum to monolayer cultures. After washing the monolayers (normal or pre-treated) three times with sterile, pre-warmed $\left(37^{\circ} \mathrm{C}\right)$ PBS or TBS, flasks or wells were filled and 'blocked' ( $30 \mathrm{~min}$ ) with pre-warmed PBS $\left(37^{\circ} \mathrm{C}\right)$ containing $3 \%(\mathrm{w} / \mathrm{v})$ bovine serum albumin (BSA). This and subsequent incubation steps were carried out at $37^{\circ} \mathrm{C}$ in an atmosphere of $\mathrm{CO}_{2} / \operatorname{air}(5: 95, \mathrm{v} / \mathrm{v})$ to maintain optimum viability of monolayers. Monolayers were then washed $(\times 3)$ with pre-warmed PBS and ureaplasma cell suspensions (fresh culture or normal or pre-treated washed suspensions) were added, $5 \mathrm{ml}$ per $25 \mathrm{~cm}^{2}$ flask or $2 \mathrm{ml}$ per well. Where required, urea was added to a final concentration of $0.05 \%(\mathrm{w} / \mathrm{v})$ at this stage. After incubation $\left(60 \mathrm{~min}, 37^{\circ} \mathrm{C}\right)$, non-adherent ureaplasmas were removed by washing $(x 4)$ with PBS or TBS $\left(37^{\circ} \mathrm{C}\right)$ over a $30 \mathrm{~min}$ period on a shaking table. Monolayers with adherent ureaplasmas were then solubilized by incubation $\left(30\right.$ min at $20^{\circ} \mathrm{C}$ ) with PBS containing $0.5 \%$ (v/v) Nonidet P40 (BDH; PBS-N). This treatment released urease from the adsorbed $U$. urealyticum and the enzyme activity was assayed to monitor adherence. (Initial experiments had shown that, under the assay conditions used, the concentration of ammonium ions released by the enzyme was related to ureaplasma population density.) Aliquots $(600 \mu \mathrm{l})$ of solubilized cells were transferred to sterile Eppendorf tubes, $120 \mu 115 \mathrm{mM}$ urea was added and after incubation $\left(15 \mathrm{~min}, 20^{\circ} \mathrm{C}\right)$ the concentration of released ammonium ions was monitored by the Bertholet assay described elsewhere (Precious et al., 1987; Thirkell et al., 1989a). Briefly, $144 \mu \mathrm{l}$ phenol nitroprusside and $144 \mu \mathrm{l}$ alkaline hypochlorite were added to the incubation and mixed well. Following further incubation $\left(20 \mathrm{~min}\right.$ at $\left.20^{\circ} \mathrm{C}\right)$, absorbances were read at $600 \mathrm{~nm}$ against a blank containing PBS-N and urea. The absorbance measured from the adherence of untreated ureaplasmas to normal monolayers (included in each set of assays as positive control) was assigned $100 \%\left(A_{\mathbf{6 0 0}}=1 \cdot 18 \pm \mathrm{sE} 0.03\right)$ and all other values were related to this figure. All assays were carried out at least in duplicate and on each occasion, as negative controls, blocked empty flasks or wells in which only tissue culture medium had been incubated prior to 'blocking' with BSA ( $A_{600}$ equivalent to $0 \%$ and automatically subtracted from all positive assays) were included. Further control assays were conducted using both types of monolayer, which were 'blocked' with BSA then incubated with either ureaplasma media, PBS or TBS, with and without added urea, or with 'spent' culture medium or with sonicated ureaplasma suspensions $\left(A_{600}=0.008 \pm \mathrm{sE} 0.003 ;\right.$ MSE Soniprep $150,3 \times 10 \mathrm{~s}$, on ice as before).

The significance (probability) of all data obtained was calculated using the Students' $t$-test.

\section{Immunoblot-overlay adherence assay of $U$. urealyticum to HeLa cell polypeptides}

Monolayers were washed $(\times 2)$ with sterile pre-warmed $\left(37^{\circ} \mathrm{C}\right)$ PBS, then $2 \mathrm{ml}$ PBS was added to each flask. Cells were scraped off and transferred to sterile Eppendorf tubes. After centrifugation $\left(11500 \mathrm{~g}, 5 \mathrm{~min}, 20^{\circ} \mathrm{C}\right)$ and washing $(\times 2)$ with PBS, pellets were suspended in solubilization buffer $(10 \mathrm{mM}$ Tris/HCl, pH 7·2, $5 \mathrm{mM}$ EDT A, $650 \mathrm{mM} \mathrm{NaCl}, 1 \mathrm{mM}$ PMSF, $0 \cdot 1 \%, \mathrm{w} / \mathrm{v}, \mathrm{NaN}_{3}$ ), sonicated (MSE Soniprep $150 ; 3 \times 10 \mathrm{~s}$ on ice), then centrifuged as above. The extracts were pooled and 
stored at $-20^{\circ} \mathrm{C}$ until required. The protein concentration in the extract was estimated as between 5 and $6 \mathrm{mg} \mathrm{m}^{-1}$ using the Low'ry method. Extracts containing $1 \mathrm{mg}$ protein $\mathrm{ml}^{-1}$ were mixed with an equal volume of 'denature mix' (Thirkell $e t$ al., $198^{\circ}$ a), boiled ( $3 \mathrm{~min}$ ), then loaded $(200 \mu \mathrm{l}$ per well) on a $15 \mathrm{~cm}$ $15^{\circ} .(\mathrm{w} / \mathrm{v})$ polyacrylamide gel. After electrophoresis as described previously (Thirkell et al., 1989a), HeI.a cell polypeptides were transferred to a nitrocellulose sheet on a semidry blotter (Ancos; $0.8 \mathrm{~mA} \mathrm{~cm}^{-2}, 60 \mathrm{~min}$ ) using $1 \mathrm{M}$ Tris, $\mathrm{pH} 111.4,20 \%(\mathrm{v} / \mathrm{v})$ methanol as both anode and cathode buffer. After rinsing with PBS, a strip was removed from the blot and stainced with $0.2 \%(\mathrm{w} / \mathrm{v})$ naphthalene black in glacial acetic acid/methanol/distilled water (10:40:50, by vol.) to confirm polypeptide transfer. The remainder of the sheet was cut into strips, blocked with PBS containing 3\% (w/v) BSA (30 min, $20^{\circ}()$ and used in adherence assays. Ureaplasma suspensions (unt reated or pre-treated suspensions in PBS, or culture) were overlaid on separate strips which were then incubated (with gentle agitation; $20^{\circ} \mathrm{C}, 60 \mathrm{~min}$ ). Strips were then washed $(3 \times 15 \mathrm{~min})$ in PBS to remove loosely adhered ureaplasmas. Avidly adhered ureaplasmas were detected by incubation of the strips with homologous polyclonal antiserum raised in rabbits $\left(1: 11110\right.$ dilution in $\left.\mathrm{PBS} ; 60 \mathrm{~min}, 20^{\circ} \mathrm{C}\right)$, washing with $\mathrm{PBS}$ $(3 \times 111 \mathrm{~min})$, then incubation in peroxidase-linked anti-rabbit Ig (Scottish Antibody Production Lnit; 1:1000 dilution in PBS; $60 \mathrm{~min}, 20^{\circ} \mathrm{C}$ ). After final washing (as above), adhered ureaplasmas were visualized using either ECL (Amersham) or 4-chloro-1-naphthol as developer. The molecular masses of HeI a polypeptides to which ureaplasmas adhered were calculated by comparison with protein standards (Gibco).

\section{RESULTS}

\section{Assay conditions}

Initial experiments were performed to ascertain the optimum number of ureaplasma cells to be incubated with the HeLa cell monolayers to demonstrate adherence. Fresh ureaplasma cultures in medium containing either horse or foetal calf serum, or PBS- or TBS-washed cell suspensions were used. An indication of the percentage of ureaplasmas adhering to the HeLa cell monolayers was gained by estimation of viable cell numbers $\left(\mathrm{ccu} \mathrm{ml}{ }^{-1}\right.$; Precious et al., 1987) using fivefold dilutions before and after incubation of the ureaplasmas with the monolayers. Irrespective of ureaplasma challenge numbers $\left(10^{4} 10^{7} \mathrm{ccu} \mathrm{ml} \mathrm{m}^{-1}\right)$, approximately $20 \%$ of the ureaplasmas added to the monolayers adhered (range 15-24\%). All subsequent assays were performed with ureaplasmas grown in medium with horse serum at around $10^{6} \mathrm{ccu} \mathrm{ml} l^{-1}$, i.e. around five ureaplasma cells per HeLa monolayer cell.

\section{Adherence of $U$. urealyticum to eukaryotic cells}

After initial experiments, all work was performed with HeL a cell monolayers since similar adherence values were obtained (using the Bertholet assay procedure) with both Hel a cell monolayers and SV40-transformed human uroepithelial cell monolayers when ureaplasmas were used at $10^{6} \mathrm{ccu} \mathrm{ml} l^{-1}$ in culture medium or buffer $\left(A_{600}\right.$ $1.18 \pm$ SE 0.030 with HeLa cell monolayers, $1.08 \pm$ SE 0.001 with SV40-transformed cells). Using the novel adherence assay, it was confirmed that neither the type of serum (horse or foetal calf) in the ureaplasma medium, nor washing and resuspension of ureaplasmas to the same cellular concentration in buffer, affected adherence.

Incubation of any ureaplasma preparation or of medium, with or without added urea, with 'blocked' plastic-ware, gave background 'adherence' values of $<1.2 \%$ compared with the positive control (monolayer incubated with ureaplasmas). Furthermore, the relative 'adherence' values given by any monolayer preparation incubated with or without added urea, but in the absence of any ureaplasma preparation, were $<0.1 \%$ (Fig. 1).

Pre-treatment of HeLa monolayers with neuraminidase reduced adherence to $13 \%$ (Fig. $1 ; P=<0.001$ ) of the positive control level, suggesting that a high proportion of the eukaryotic receptors terminate in sialic acid, a finding in agreement with a previous study using human erythrocytes (Saada et al., 1991). Pre-treatment of ureaplasmas with NANA also reduced adherence

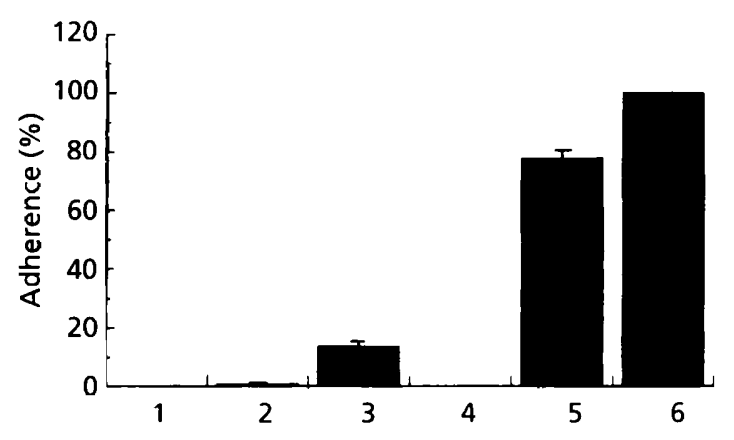

Fig. 1. Adherence of ureaplasma cells to HeLa cell monolayers. Columns: 1 , HeLa cells alone; 2 , ureaplasma cells alone; 3, HeLa cells pre-treated with neuraminidase, plus ureaplasma cells; 4 , HeLa cells plus ureaplasma cells pre-treated with HeLa cell extract; 5, HeLa cells plus ureaplasma cells pre-treated with NANA; 6 , positive control-HeLa cells plus ureaplasma cells. Error bars indicate SE.

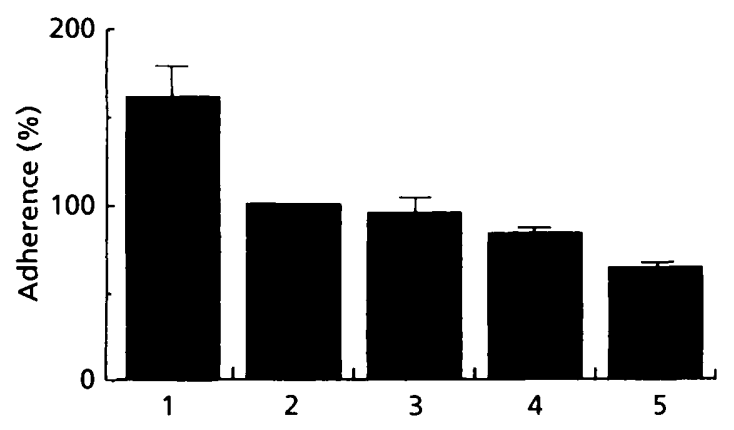

Fig. 2. Effect of urea and trypsin on adherence of ureaplasma cells to Hela cell monolayers. Columns: 1, HeLa cells plus ureaplasma cells with added urea; 2 , positive control-HeLa cells plus ureaplasma cells; 3 , HeLa cells plus ureaplasma cells pre-treated with $100 \mu \mathrm{g}$ trypsin $\mathrm{ml}^{-1} ; 4$, HeLa cells plus ureaplasma cells pre-treated with $200 \mu \mathrm{g}$ trypsin $\mathrm{ml}^{-1} ; 5$, HeLa cells plus ureaplasma cells pre-treated with $500 \mu \mathrm{g}$ trypsin $\mathrm{ml}^{-1}$. Error bars indicate SE. 
significantly (to $78 \%, P=<0.001$; Fig. 1) confirming the importance of sialic acid residues in the recognition process.

The specific binding of ureaplasmas to HeLa cells was confirmed by demonstrating that pre-treatment of ureaplasmas with HeLa cell extracts abolished adherence (Fig. 1).

Pre-incubation of ureaplasmas with homologous polyclonal antiserum reduced adherence to $37 \%$ of the positive control level, with heterologous polyclonal antiserum (raised against serotype 4) adherence was reduced to $68 \%$ of the positive control, and pre-treatment with $\mathrm{mAbs}$ against five distinct epitopes of the serotype8 -specific $96 \mathrm{kDa}$ surface-expressed antigen reduced adherence, to between 70 and $80 \%$ (results were not significantly different from each other) of the positive control level, depending upon the $\mathrm{mAb}$ used in the assay. These data suggest that some ureaplasma adhesins are antigenic, that both species- and serotype-specific adhesins are expressed, and that the serotype-8-specific antigen may also be an adhesin.

Pre-treatment of ureaplasmas with a mAb against the $16 / 17 \mathrm{kDa}$ serocluster-specific antigens, or with a series of uncharacterized $\mathrm{mAbs}$ raised against serotype 8 or with $\mathrm{mAbs}$ raised against non-ureaplasma antigens, failed to have any significant affect on adhesion.

Fig. 2 indicates that at least some of the ureaplasma adhesins appear to be protease-sensitive in a dosedependent manner and that pre-treatment of the ureaplasmas with trypsin at $500 \mu \mathrm{g} \mathrm{ml}^{-1}$ reduced adherence by $36 \%$. In addition, the combination of trypsinization $\left(200 \mu \mathrm{g}\right.$ trypsin $\left.\mathrm{ml}^{-\mathbf{1}}\right)$ followed by treatment with homologous polyclonal antiserum or by serotypespecific $\mathrm{mAb}(\mathrm{Uu} 8 / 5)$ produced adherence values of 44 and $84 \%$, respectively, not significantly different to adherence levels obtained after pre-treatment with the antibodies alone. Whereas trypsin or non-enzymic pretreatments of ureaplasmas did not result in any loss of viability (as shown by determination of ccu ml-1), pretreatment with either proteinase $\mathrm{K}$ or with papain resulted in a $10^{4}-10^{5}$-fold decrease in $\mathrm{ccu} \mathrm{ml}^{-1}$, and thus these suspensions could not be used in adherence assays.

\section{Effect of urea on adherence}

It was also noted that addition of urea (final concentration $0.05 \%, \mathrm{w} / \mathrm{v}$ ) to washed ureaplasma suspensions immediately prior to incubation with monolayers produced an increase in adherence to $160 \%$ (Fig. $2 ; P=<0.001$ ) of that of controls without urea. In addition, inclusion of urea after the pre-treatment of ureaplasmas with saccharide, antibody or trypsin, as described above, increased adherence similarly.

\section{Immunoblot adherence assay}

U. urealyticum serotype 8 (T960) adhered to a number of HeLa cell polypeptides, a triplet set around $30 \mathrm{kDa}$, and three others of 17,16 and $14 \mathrm{kDa}$ apparent molecular

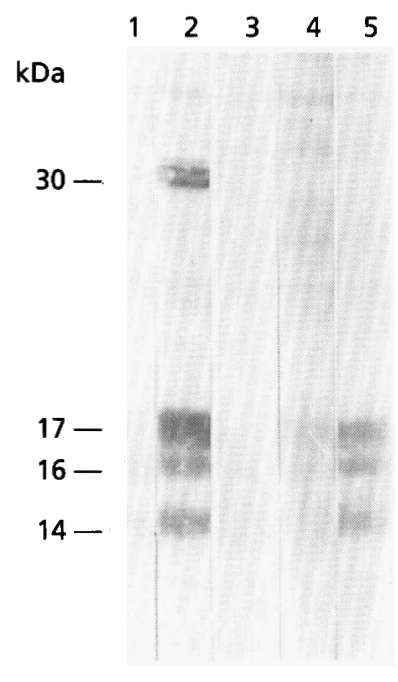

Fig. 3. Immunoblot adherence assays for $U$. urealyticum to HeLa cell components. Only the lower part of the $15 \%$ gel is displayed since no other bands were apparent with molecular masses greater than those seen. Lanes: 1 , dry blot - HeLa cell polypeptides alone (no ureaplasmas added); 2 , dry blot - HeLa cell polypeptides overlaid with a washed ureaplasma suspension (in PBS); 3, dry blot-HeLa cell polypeptides overlaid with a washed ureaplasma suspension pre-treated with HeLa cell extract; 4, dry blot - HeLa cell polypeptides overlaid with a washed ureaplasma suspension pre-treated with trypsin $(200 \mu \mathrm{g}$ $\left.\mathrm{ml}^{-1}\right) ; 5$, dry blot-polypeptides of HeLa cells pre-treated with neuraminidase, overlaid with washed ureaplasma suspension.

mass (Fig. 3). It is seen that pre-treatment of the ureaplasmas with HeLa cell extract (lane 3) abolished all adherence, whereas pre-treatment of HeLa cells with neuraminidase prior to electrophoresis abolished adherence to the triplet around $30 \mathrm{kDa}$; adherence to the lower molecular mass polypeptides was not significantly reduced (lane 5). However, pre-treatment of HeLa cell monolayers with neuraminidase reduced ureaplasma adherence to $13 \%$ (Fig. 1), and the pattern of the $17 / 16 / 14 \mathrm{kDa}$ bands in Fig. 3 resembles that expected for binding to histones. Thus it is possible that the lower molecular mass bands seen in Fig. 3 are due to ionic interactions between ureaplasmas and the basic histones and that the major $\mathrm{HeLa}$ cell monolayer recognition components are represented by the triplet around $30 \mathrm{kDa}$. Confirmation of this requires further study. It was also observed that proteolysis of ureaplasmas with trypsin significantly reduced their adherence to the components in the 14-17 $\mathrm{kDa}$ range and abolished adherence to the triplet components, suggesting that most if not all of the ureaplasma adhesin(s) is/are proteinaceous.

These data were reproduced over several months by three independent workers.

\section{DISCUSSION}

Methodologies for the study of ureaplasma adherence which utilize direct interaction of ureaplasma cells with eukaryotic cells were evaluated. We developed a novel technique whereby adherence was measured using the 
Bertholet assay to determine ammonia released from urea consequent upon urease activity of adhered ureaplasmas. This technique could be easily quantified and used to compare adherence under different conditions. A previous study (Saada et al., 1991) on adherence of ureaplasmas to human erythrocytes utilized $\left[{ }^{35} \mathrm{~S}\right]$ methionine labelling. Briefly, after normal culture, centrifugation and washing, the pellets were suspended in a sulphate-free buffer containing unlabelled amino acids and $\left[{ }^{35} \mathrm{~S}\right]$ methionine. After further incubation and a 'cold chase', the cells were used for adherence studies. We found that this technique was not reproducible since, on different occasions, very variable labelling results were obtained. In addition, attempts were made to harvest eukaryotic cells with adherent ureaplasmas onto filter membranes (pore size up to $5 \mu \mathrm{m}$ ). We noted that ureaplasmas adhered nonspecifically to the filter membranes irrespective of whether they were 'blocked' with BSA or not (data not shown). We therefore developed the adherence assay described herein to overcome the difficulties encountered with other assays.

Negative control data inferred that, as in other studies of mycoplasma adherence (e.g. Washburn et al., 1993), nonspecific binding of ureaplasmas to plasticware is not a significant factor. Also, it was shown that monolayers of either HeLa cells or SV40-transformed human uroepithelial cells, blocked and incubated with ureaplasma medium or buffer, with or without added urea, gave an apparent background 'adherence' of $<0.1 \%$.

Initial experiments showed that irrespective of the ureaplasma cell to $\mathrm{HeLa}$ cell multiplicity used, approximately $20 \%$ of the ureaplasmas always adhered to monolayers. Because of the low cell yields of ureaplasmas in culture and the problems associated with ureaplasma pellet resuspension, high ureaplasma cell to HeLa cell multiplicities could not be accurately investigated. The $20 \%$ attachment indicated that either the receptors on the epithelial cell surfaces were not saturated by the ureaplasmas at the multiplicities applied, broadly in line with a previous report also using HeLa cells (Alfa et al., 1986), or that at any time, only a proportion of ureaplasma cells may express adhesins. It is also possible that the laboratory strain of $U$. urealyticum may have lost some of its capacity to adhere through passage and that fresh clinical isolates may adhere to a greater extent. This did not appear to be the case in a previous report (Saada $e t$ al., 1991) where, however, many of the ureaplasmas may have been lysed as a result of the very vigorous resuspension protocol followed. The specific nature of the ureaplasma adherence to HeLa cell monolayers was confirmed when pre-incubation of ureaplasmas with HeLa cell extracts prior to exposure to the monolayers resulted in abolition of adherence. However, since total abolition was not achieved after pre-treatment of $\mathrm{HeLa}$ cells with neuraminidase ( $13 \%$ adherence remaining), at least two types of eukaryotic cell receptor may exist. This finding is in keeping with the observation that $\mathrm{HeLa}$ cell components also inhibit cytadherence of Chlamydia trachomatis (Joseph \& Bose, 1992). It has been suggested that ureaplasma adhesins may be partially blocked by medium components when cells are grown in medium containing horse serum (Masover et al., 1977); however, in this study, similar adherence values were obtained irrespective of whether horse or foetal calf serum, which binds poorly if at all to ureaplasmas (Precious et al., 1987), was present in the growth medium. This suggests that any medium component which can bind to ureaplasma adhesin(s) does so with a lower affinity than do receptors on epithelial cell surfaces.

Adhesin(s) of $U$. urealyticum were sensitive to trypsin in a dose-dependent manner (adherence reduced by up to $36 \%$ ), suggesting that they possess a protein moiety. This is similar to a result reported for adherence to erythrocytes (Saada et al., 1991). It was also shown that trypsinization (and all ureaplasma pre-treatments other than with proteinase $\mathrm{K}$ or papain used in these experiments) failed to alter ureaplasma viability (cf. Masover et al., 1977). However, since adherence was not abolished at the highest trypsin concentration used, it may be that not all adhesin molecules are sensitive to proteolysis by trypsin and that more than one type of ureaplasma adhesin is present, although aggregation may limit the availability of the adhesin(s) to trypsin.

Pre-incubation of ureaplasmas with mAbs against any of the five known epitopes of the $96 \mathrm{kDa}$ ureaplasma serotype-specific antigen gave a statistically significant reduction (up to $30 \%)$ in adherence $(P=<0.001)$. This was of the same order as that achieved by pre-incubation with $500 \mu \mathrm{g}$ trypsin $\mathrm{ml}^{-1}$, and the fact that SDS-PAGE of trypsinized ureaplasmas, followed by immunoblotting, revealed that the $96 \mathrm{kDa}$ antigen was trypsin-sensitive (data not shown) makes it attractive to propose that the immunodominant $96 \mathrm{kDa}$ serotype-specific antigen is also an adhesin. In an attempt to confirm this, by pre-treating HeLa cell monolayers with the antigen, the antigen was purified by immunoaffinity chromatography (Thirkell $e t$ al., 1989b). However, being a very hydrophobic molecule, the $96 \mathrm{kDa}$ antigen was only soluble in the presence of detergent (in this case Nonidet P40) which was capable of dislodging the HeLa cell monolayers. Thus, the relevant investigation had to be abandoned.

Whilst pre-incubation of ureaplasmas with the anti-16/17$\mathrm{kDa} \mathrm{mAb}$, with uncharacterized $\mathrm{mAbs}$ raised against serotype 8 or with $\mathrm{mAbs}$ against non-mycoplasma antigens failed to reduce adherence, other antigens do seem to be adhesins in this organism. Thus adherence of ureaplasmas to HeLa cells was reduced markedly by pretreatment with homologous polyclonal antiserum (by $64 \%$ ) and to a lesser extent (by $32 \%$ ) by heterologous antiserum raised against serotype 4 . The latter finding suggests that there may well be both serotype-specific and species-specific adhesins and that adherence is multifactorial.

Urea is integral to the metabolism of $U$. urealyticum and its hydrolysis appears to significantly increase cellular adherence (to around $160 \%$ of the control level) to $\mathrm{HeLa}$ cell monolayers. This finding was in contrast to a previous report (Saada et al., 1991) where it was stated that urea had no effect on adherence of ureaplasmas to erythrocytes. 
Pre-treatment of HeLa cell monolayers with neuraminidase or pre-treatment of ureaplasma suspensions with NANA resulted in statistically significant reductions in adherence. This is in broad agreement with a previous report (Saada et al., 1991) which indicated that several serotypes of $U$. urealyticum adhere to erythrocytes via NANA residues. Thus, ureaplasma adherence involves NANA as a ligand (bur probably not the sole ligand) receptor molecule. Evidence for the presence of at least six putative HeI a cell receptor: was obtained using the novel immunoblot-overlay ad. herence assay. This is the first report of the use of this type of assay with any mycoplasma. Of these six receptors (30 kDa triplet, $17,16,14 \mathrm{kDa})$, only three $(30 \mathrm{kDa}$ triplet) were sensitive to neuraminidase treatment; the others may be histones. This assay was not performed using either the heterologous polyclonal antiserum raised against serotype 4 or the anti-96-kDa mAbs as first antibody, since we wished to maximize detection of serotype- 8 adherence. In addition, the effect of SDS or other detergents on the assay was not investigated since we had shown (data not included) that such detergents lyse ureaplasmas and we wished to avoid detection of adhered cytoplasmic components. Further investigations are necessary in order to characterize ureaplasma receptors and the ability of the HeLa cell extracts to inhibit binding offers a plausible route. With respect to additional receptors, it has been shown (Lingwood et al., 1990) that U. urealyticum may adhere to certain sulphogalactolipids which occur in urogenital tissues and involvement of such components cannot be ruled out, although their significance in the process of adherence has yet to be fully demonstrated.

These studies indicate that ureaplasma adherence to eukaryotic cells can be readily demonstrated and quantified using the techniques developed here, which should therefore facilitate further investigations on the characterization of both the eukaryotic cell receptor(s) and the ureaplasma adhesin(s) involved.

\section{ACKNOWLEDGEMENTS}

This work was supported by a grant (G8924533) from the Medical Research Council. I. Armitt is thanked for technical assistance.

\section{REFERENCES}

Alfa, M. J., Chen, M. H. \& Robertson, J. A. (1986). A HeLa cell model for studying attachment of Ureaplasma urealyticum. Abstracts of papers presented at the 6 th International Congress of the International Organisation for Mycoplasmology, Birmingham, Alabama, USA. Abstract no. PI-50, p. 161.
Armitage, M. P., Bryant, P. E. \& Riches, A. C. (1991). Cytogenetic responses of human uroepithelial cell lines and a malignant bladder carcinoma cell line to X-rays. Mutagenesis 6, 515-518.

Busalo, F., Zanchetta, R. \& Bertoloni, G. (1984). Mycoplasmic localization patterns in spermatozoa from infertile men. Fertil Steril $42,412-416$.

Dulbecco, R. \& Vogt, M. (1954). Plaque formation and isolation of pure lines with poliomyelitis virus. J Exp Med 99, 167-182.

Joseph, T. D. \& Bose, S. K. (1992). Surface components of HeLa cells that inhibit cytadherence of Chlamydia tracbomatis. FEMS Microbiol Lett 91, 177-180.

Lingwood, C., Schramyr, S. \& Quinn, P. A. (1990). Male germ cell specific sulfogalactoglycerolipid is recognised and degraded by mycoplasmas associated with male infertility. I Cell Physiol 142, $170-176$.

McGarrity, G. J. \& Kotani, H. (1986). Ureaplasma-eukaryotic cell interactions 'in vitro'. Pediatr Infect Dis J 5, S316 S318.

Masover, G. K., Palant, M., Zerrudo, Z. \& Hayflick, L. (1977). Interaction of Ureaplasma urealyticum with eukaryotic cells in vitro. In Non-gonococcal Uretbritis and Related Infections. Edited by D. Hobson \& K. K. Holmes. Washington: American Society for Microbiology.

Precious, B. L., Thirkell, D. \& Russell, W. C. (1987). Preliminary characterisation of the urease and a $96 \mathrm{kDa}$ surface-expressed polypeptide of Ureaplasma urealyticum. J Gen Microbiol 133, 2659-2670.

Razin, S. \& Jacobs, E. (1992). Mycoplasma adhesion. J Gen Microbiol 138, $407-422$.

Robertson, J. A. \& Sherburne, R. (1991). Hemadsorption by colonies of Ureaplasma urealyticum. Infect Immun 59, 2203 2206.

Russell, W. C., Newman, C. \& Williamson, D. H. (1975). A simple cytochemical technique for demonstration of DNA in cells infected with mycoplasmas and viruses. Nature 253, 461-462.

Saada, A. -B., Terespolski, Y., Adoni, A. \& Kahane, I. (1991). Adherence of Ureaplasma urealyticum to human erythrocytes. Infect Immun 59, 467-469.

Shepard, M. C. \& Masover, G. K. (1979). Special features of ureaplasmas. In The Mycoplasmas, vol. 1, pp. 451-494. Edited by M. F. Barile \& S. Razin. New York: Academic Press.

Thirkell, D., Myles, A. D., Precious, B. L., Frost, J. S., Woodall, J. C., Burdon, M. G. \& Russell, W. C. (1989a). The urease of Ureaplasma urealyticum. J Gen Microbiol 135, 315-323.

Thirkell, D., Myles, A. D. \& Russell, W. C. (1989b). Serotype 8- and serocluster-specific surface-expressed antigens of Ureaplasma urealyticum. Infect Immun 57, 1697-1701.

Thirkell, D., Myles, A. D. \& Precious, B. L. (1990). Characterization of urease and surface-expressed antigens of Ureaplasma urealyticum. Zentralbl Bakteriol Suppl 20, 546-554.

Washburn, L. R., Hirsch, S. \& Voelker, L. L. (1993). Mechanisms of attachment of Mycoplasma artbritidis to host cells 'in vitro'. Infect Immun 61, 2670-2680.

Received 7 February 1994; revised 11 May 1994; accepted 1 June 1994. 